\title{
Persepsi Pasien Rawat Jalan di Rumah Sakit PKU Muhammadiyah Unit 1 Yogyakarta terhadap Kualitas Obat Generik Ditinjau dari Dimensi Safety, Efficacy, dan Acceptability
}

\author{
*Nurul Mardiati ${ }^{1}$, Sampurno ${ }^{2}$, Chairun Wiedyaningsih ${ }^{3}$ \\ ${ }^{1}$ Sekolah Tinggi Farmasi Borneo Lestari, Banjarbaru \\ ${ }^{2}$ Fakultas Farmasi Universitas Pancasila, Jakarta \\ ${ }^{3}$ Fakultas Farmasi Universitas Gadjah Mada, Yogyakarta \\ *Email: nurulmardiati2007@gmail.com
}

\begin{abstract}
ABSTRAK
Roadmap upaya peningkatan penggunaan obat generik sebenarnya sudah dilakukan pemerintah jauh sebelum resmi memberlakukan skema Jaminan Kesehatan Nasional (JKN). Akan tetapi persepsi pasien terhadap obat generik di masa penerapan JKN ini dinilai oleh banyak pengamat masih buruk. Obat generik masih dianggap sebagai obat murah sehingga mutunya diragukan. Penelitian ini dilakukan untuk mengetahui persepsi pasien terhadap kualitas obat generik ditinjau dari dimensi safety, efficacy, dan acceptability. Rancangan penelitian ini adalah penelitian deskriptif-analitik dengan pendekatan kuantitatif, desain survey cross sectional. Jumlah sampel sebanyak 150 responden. Alat penelitian yang digunakan adalah kuesioner. Analisis data yaitu analisis deskriptif. Hasil penelitian menunjukkan bahwa persepsi pasien terhadap kualitas obat generik mayoritas tergolong baik yaitu sebesar 113 responden $(\mathbf{7 5 , 3 \%})$. Rata-rata skor mulai dari yang terbesar berturut-turut safety $(3,02)$; efficacy $(2,75)$; dan acceptability $(2,73)$. Seluruh rata-rata skor jawaban responden pada item-item pernyataan dimensi safety, efficacy, dan acceptability menunjukkan persepsi yang baik pasien terhadap kualitas obat generik.
\end{abstract}

Kata kunci: Persepsi Pasien, Kualitas, Obat Generik

\section{ABSTRACT}

Roadmap for improving the use of generik drugs actually has been done long before the government commit officially JKN scheme. However, the patient's perception of generik drugs is still bad in JKN era by considering many observers. Generic drugs are still regarded as a cheap drug so its quality is doubtful.This study was conducted to determine the patient's perception about quality of generik drugs which was studied based on safety, efficacy, and acceptability dimensions. The design of this research is descriptive-analytic study with a quantitative approach, cross-sectional survey. The sample size was 150 respondents. Research of tools used was questionnaire. Data analysis was descriptive test. The results of the research showed that the majority of patients $(75,3 \%)$ have good perception to the quality of generic drugs. Average score from the largest sequentially safety (3,02), efficacy (2,75), and acceptability $(2,73)$. All of average score of respondents' answers on items safety, efficacy, and acceptability dimensions showed good perception of patients on the quality of generic drugs.

Keywords: Patient's perception, Quality, Generik drug 
Prosiding Seminar Nasional Kefarmasian, Hal: 25-39

Sabtu, 8 Oktober 2016, Hotel Aria Barito Banjarmasin

ISBN: 978-602-73121-1-1

\section{PENDAHULUAN}

Semua warga negara berhak atas kesehatannya termasuk masyarakat miskin. Oleh karena itu, diperlukan suatu sistem yang mengatur pelaksanaan bagi upaya pemenuhan hak warga negara untuk tetap hidup sehat dengan mengutamakan pada pelayanan kesehatan bagi masyarakat. Sebagaimana diamanatkan konstitusi dan Undang-undang Republik Indonesia No. 40 Tahun 2004 tentang Sistem Jaminan Sosial Nasional, dalam rangka memenuhi hak masyarakat memasuki tahun 2014 pemerintah telah secara resmi menggulirkan skema Jaminan Kesehatan Nasional (JKN).

Sistem jaminan ini akan menciptakan perubahan mendasar di bidang sistem jaminan kesehatan seperti penataan standardisasi pelayanan, standardisasi tarif, penataan formularium, dan penggunaan obat rasional yang berdampak pada kendali mutu dan kendali biaya. Upaya-upaya tersebut pada aspek pelayanan obat sendiri, maka seluruh fasilitas kesehatan diwajibkan mengacu pada Formularium Nasional (Fornas). Obat-obatan dalam Fornas ini sebagian besar merupakan obat generik. Hal ini berkaitan dengan keputusan pemerintah agar dibudayakan penggunaan obat generik karena obat generik berkhasiat baik dengan harga ekonomis (Anonim,
2012). Salah satu implikasi yang diharapkan dari kebijakan tersebut adalah meningkatnya penggunaan obat generik.

Mayoritas konsumen Indonesia menganggap obat generik sebagai obat berkualitas rendah dengan harga rendah (Jakarta Post, 2010). Persepsi tersebut pada dasarnya tidak benar sebab industri farmasi merupakan salah satu industri yang regulasinya paling ketat. Pemerintah menerapkan standar manufaktur nasional ketat yang dikenal sebagai CPOB (Cara Pembuatan Obat yang Baik) atau c-GMP (Current Good Manufacturing Practice) (Priyambodo, 2007). Setiap obat baik obat generik maupun obat branded generik dan paten harus memenuhi standar kualitas sebelum diluncurkan ke pasar. Dimensi kualitas obat menurut konsumen menggunakan dimensi yang sesuai dengan dimensi kualitas yang digunakan di seluruh dunia oleh pemerintah dalam menilai kualitas obat. Pemerintah di seluruh dunia menilai kelayakan obat yang diluncurkan ke pasar berdasarkan pada safety, efficacy, dan acceptability (Firth, 2001).

Roadmap upaya meningkatkan penggunaan obat generik sebenarnya sudah dilakukan pemerintah jauh sebelum resmi menggulirkan skema $\mathrm{JKN}$, dimulai dengan dikeluarkannya Peraturan Menteri Kesehatan No. 085/Menkes/PER/I/1989 
Prosiding Seminar Nasional Kefarmasian, Hal: 25-39

Sabtu, 8 Oktober 2016, Hotel Aria Barito Banjarmasin

ISBN: 978-602-73121-1-1

tentang Kewajiban Menuliskan Resep dan/atau Menggunakan Obat Generik di Fasilitas Pelayanan Kesehatan Pemerintah (dicabut dan dinyatakan tidak berlaku digantikan dengan Peraturan Menteri Kesehatan Republik Indonesia No. HK.02.02/MENKES/068/I/2010).

Demikian pula dengan dikeluarkannya Peraturan Menteri Kesehatan No. 988/MENKES/SKNIII/2004 tentang pencantuman nama generik pada label obat (dicabut dan dinyatakan tidak berlaku digantikan dengan Keputusan Menteri Kesehatan Menteri Kesehatan Republik Indonesia No. 068/MENKES/SK/II/2006.

Akan tetapi persepsi pasien terhadap obat generik di masa penerapan JKN ini dinilai oleh banyak pengamat masih buruk, salah satunya yang menyatakan bahwa masih ada persepsi yang salah tentang obat generik, yaitu obat generik dianggap sebagai obat murah sehingga mutunya diragukan (Binfar Kementerian Kesehatan RI, 2014). Persepsi pasien yang buruk terhadap obat generik dapat mengakibatkan sugesti yang buruk sehingga mempengaruhi pengalaman kesembuhan pasien (Waber et al., 2008).

Tujuan penelitian ini adalah untuk mengetahui persepsi pasien rawat jalan di RS PKU Muhammadiyah unit 1 Yogyakarta terhadap kualitas obat generik ditinjau dari dimensi safety, efficacy, dan acceptability.

\section{METODE PENELITIAN}

\section{A. Jenis Penelitian}

Rancangan penelitian ini adalah penelitian deskriptif-analitik dengan pendekatan kuantitatif, desain survey cross sectional. Alat yang digunakan dalam pelaksanaan penelitian ini adalah kuesioner. Jumlah sampel yang digunakan dalam penelitian ini dihitung dengan menggunakan rumus Slovin, diperoleh 150 responden. Cara pengambilan sampel dilakukan dengan simple random sampling. Subyek penelitian yang digunakan dalam penelitian ini adalah pasien rawat jalan di RS PKU Muhammadiyah unit 1 Yogyakarta.

\section{B. Tempat dan Waktu Penelitian}

Penelitian ini dilakukan di RS PKU Muhammadiyah unit 1 Yogyakarta. Waktu penelitian dilaksanakan pada bulan Januari 2015-Februari 2015.

\section{Analisis Data}

Analisis deskriptif digunakan untuk mendeskripsikan persepsi pasien terhadap obat generik diinjau dari dimensi safety, efficacy, dan acceptability berdasarkan skor jawaban responden. Persepsi pasien terhadap obat generik diinjau dari dimensi safety, efficacy, dan acceptability digolongkan ke dalam empat kategori 
Prosiding Seminar Nasional Kefarmasian, Hal: 25-39

Sabtu, 8 Oktober 2016, Hotel Aria Barito Banjarmasin

ISBN: 978-602-73121-1-1

yaitu sangat baik, baik, buruk, dan sangat buruk.

\section{HASIL DAN PEMBAHASAN}

\section{A. Analisis Deskriptif Persepsi Pasien terhadap Kualitas Obat Generik}

Persepsi pasien rawat jalan di RS

PKU Muhammadiyah unit 1 Yogyakarta terhadap kualitas obat generik dapat dilihat pada tabel I.

Tabel I. Persepsi Pasien Rawat Jalan di RS PKU Muhammadiyah Unit 1 Yogyakarta terhadap Kualitas Obat Generik

\begin{tabular}{|l|c|c|}
\hline \multicolumn{1}{|c|}{$\begin{array}{c}\text { Persepsi Pasien terhadap } \\
\text { Kualitas Obat Generik }\end{array}$} & Jumlah & Persentase \\
\hline Sangat baik & 11 & $7,3 \%$ \\
\hline Baik & 113 & $75,3 \%$ \\
\hline Buruk & 26 & $17,3 \%$ \\
\hline Sangat buruk & 0 & $0 \%$ \\
\hline
\end{tabular}

Berdasarkan tabel 1 diketahui bahwasanya dari 150 responden, persepsi pasien terhadap kualitas obat generik mayoritas yaitu sebesar 113 responden (75,3\%) tergolong baik. Secara umum baik dari dimensi safety, efficacy, maupun acceptability mayoritas pasien memiliki persepsi yang baik terhadap kualitas obat generik.

\section{B. Persepsi Pasien Rawat Jalan di RS PKU Muhammadiyah Unit 1 Yogyakarta terhadap Kualitas Obat Generik Ditinjau dari Dimensi Safety}

Persepsi pasien rawat jalan di RS PKU Muhammadiyah unit 1 Yogyakarta terhadap kualitas obat generik ditinjau dari dimensi safety dapat dilihat tabel 2.

Dimensi safety merupakan syarat kualitas yang menyangkut keamanan obat termasuk efek samping yang ditimbulkannya (Departemen Kesehatan RI, 1983). Safety menurut konsumen didefinisikan sebagai tingkat konsekuensi atau resiko atas penggunaan obat, merujuk kepada potensi adanya efek samping dan kontraindikasi (Urbanus, 2013).

Berdasarkan tabel II, dapat diketahui bahwasanya rata-rata skor jawaban responden terkait dimensi safety adalah 3,02. Hal ini bermakna bahwasanya kualitas obat generik dari dimensi safety secara rata-rata dipersepsikan dengan baik oleh responden. Pasien secara umum percaya dengan safety obat generik. Skor rata-rata jawaban responden dari dimensi safety berdasarkan analisis data yang dilakukan merupakan skor yang tertinggi dibandingkan dengan kedua dimensi lainnya, yaitu efficacy dan acceptability.

Hal ini bermakna bahwa safety merupakan dimensi kualitas yang dipersepsikan paling baik oleh pasien dibandingkan dengan dimensi kualitas lainnya. 
Prosiding Seminar Nasional Kefarmasian, Hal: 25-39

Sabtu, 8 Oktober 2016, Hotel Aria Barito Banjarmasin

ISBN: 978-602-73121-1-1

Tabel II. Distribusi Jawaban Responden tentang Persepsi

Pasien Rawat Jalan di RS PKU Muhammadiyah

Unit 1 Yogyakarta terhadap Kualitas Obat

Generik Ditinjau dari Dimensi Safety

\begin{tabular}{|c|c|c|c|c|c|c|c|c|c|c|}
\hline \multirow[t]{2}{*}{ Pernyataan } & \multirow{2}{*}{$\begin{array}{c}\text { Sub } \\
\text { dimensi }\end{array}$} & \multicolumn{2}{|c|}{ STS } & \multicolumn{2}{|c|}{ TS } & \multicolumn{2}{|c|}{$\mathbf{S}$} & \multicolumn{2}{|c|}{ SS } & \multirow{2}{*}{ Rata-rata } \\
\hline & & $\mathbf{n}$ & $\%$ & $\mathbf{n}$ & $\%$ & $\mathrm{n}$ & $\%$ & $\mathbf{n}$ & $\%$ & \\
\hline $\begin{array}{l}\text { Label berisi informasi obat yang jelas } \\
\text { memastikan bahwa obat generik aman } \\
\text { digunakan ketika sampai di tangan saya } \\
\text { sebagai konsumen }\end{array}$ & Label obat & 2 & $1,3 \%$ & 4 & $2,7 \%$ & 90 & $60,0 \%$ & 54 & $36,0 \%$ & 3,31 \\
\hline $\begin{array}{l}\text { Proses produksi obat generik mampu } \\
\text { memastikan bahwa obat generik aman dan } \\
\text { layak dikonsumsi ketika sampai di tangan } \\
\text { saya sebagai konsumen }\end{array}$ & Keamanan & 0 & $0 \%$ & 10 & $6,7 \%$ & 101 & $67,3 \%$ & 39 & $26,0 \%$ & 3,19 \\
\hline $\begin{array}{l}\text { Dibandingkan dengan obat branded, obat } \\
\text { generik memiliki efek samping yang lebih } \\
\text { banyak }\end{array}$ & $\begin{array}{l}\text { Efek } \\
\text { samping }\end{array}$ & 9 & $6,0 \%$ & 106 & $70,7 \%$ & 31 & $20,7 \%$ & 4 & $2,7 \%$ & 2,80 \\
\hline $\begin{array}{l}\text { Saya percaya keamanan obat generik } \\
\text { karena mencantumkan label yang lengkap } \\
\text { (nama obat/zat aktif, tanggal kadaluarsa, } \\
\text { indikasi, dosis/aturan pakai, nama \& } \\
\text { alamat pabrik, no batch, dan no registrasi) }\end{array}$ & Label obat & 1 & $0,7 \%$ & 17 & $11,3 \%$ & 110 & $73,3 \%$ & 22 & $14,7 \%$ & 3,02 \\
\hline $\begin{array}{l}\text { Proses distribusi obat generik mampu } \\
\text { memastikan bahwa obat generik aman dan } \\
\text { layak dikonsumsi ketika sampai di tangan } \\
\text { saya sebagai konsumen }\end{array}$ & Keamanan & 1 & $0,7 \%$ & 12 & $8,0 \%$ & 125 & $83,3 \%$ & 12 & $8,0 \%$ & 2,99 \\
\hline $\begin{array}{l}\text { Saya kurang yakin dengan keamanan obat } \\
\text { generik }\end{array}$ & Keamanan & 12 & $8,0 \%$ & 121 & $80,7 \%$ & 16 & $10,7 \%$ & 1 & $0,7 \%$ & 2,96 \\
\hline $\begin{array}{l}\text { Obat generik disetujui peredarannya oleh } \\
\text { BPOM sebagaimana obat branded di } \\
\text { Indonesia }\end{array}$ & Keamanan & 3 & $2,0 \%$ & 20 & $13,3 \%$ & 118 & $78,7 \%$ & 9 & $6,0 \%$ & 2,89 \\
\hline
\end{tabular}

Keterangan:

STS: Sangat tidak setuju

TS : Tidak setuju

S : Setuju

SS : Sangat setuju

Persepsi pasien terhadap kualitas obat generik berdasarkan rata-rata skor jawaban responden mulai dari yang tertinggi hingga yang terendah berturutturut yaitu safety, efficacy dan acceptability. Data selengkapnya dapat dilihat pada tabel 3 dan 4. Rata-rata skor jawaban responden pada item-item pernyataan dimensi safety menunjukkan persepsi yang baik pasien terhadap kualitas obat generik. Mayoritas responden yaitu $101(67,3 \%)$ dan $125(83,3 \%)$ berturutturut menyatakan setuju proses produksi dan distribusi obat generik mampu memastikan bahwa generik aman serta layak dikonsumsi ketika sampai ditangan pasien sebagai konsumen. Sebagian besar responden yaitu $121(80,7 \%)$ menyatakan yakin dengan keamanan obat generik. Hasil penelitian ini sejalan dengan Excellus (2007) yang menyatakan bahwasanya mayoritas $90 \%$ responden yakin bahwasanya obat generik sama amannya dengan obat branded.

Mayoritas $118(78,7 \%)$ responden juga setuju bahwasanya obat generik disetujui peredarannya oleh Balai Pengawas Obat dan Makanan (BPOM) sebagaimana obat branded di Indonesia. Hasil penelitian ini sejalan dengan 
Prosiding Seminar Nasional Kefarmasian, Hal: 25-39

Sabtu, 8 Oktober 2016, Hotel Aria Barito Banjarmasin

ISBN: 978-602-73121-1-1

Excellus (2007) yang menyatakan mayoritas $90 \%$ responden setuju bahwasanya obat generik disetujui peredarannya oleh FDA (Food and Drug Administration) sebagaimana obat branded. Terkait pernyataan ini, langkah mudah yang dapat dilakukan pasien yaitu melakukan pemeriksaan nomor registrasi yang tercantum pada kemasan ketika membeli atau menerima obat. Nomor registrasi merupakan nomor identitas yang dikeluarkan oleh BPOM setelah proses registrasi obat tersebut disetujui. Bila tidak tercantum nomor registrasi, obat tersebut kemungkinan ilegal atau bahkan palsu. Nomor registrasi yang dicantumkan sebagai tanda izin edar absah yang diberikan oleh pemerintah pada setiap kemasan obat dipersepsikan konsumen sebagai bentuk pemastian bahwasanya obat generik disetujui peredarannya oleh BPOM sebagaimana obat branded.

Item pernyataan dengan skor tertinggi menunjukkan persepsi yang sangat baik terhadap kualitas obat generik, yaitu terkait label obat. Hampir semua informasi keselamatan obat yang dibutuhkan oleh konsumen secara ilmiah dapat ditemukan di label pada kemasan obat (Urbanus, 2013). Label obat umumnya memuat informasi seperti nama obat/zat aktif, tanggal kadaluarsa, indikasi, dosis/aturan pakai, nama \& alamat pabrik, no batch, dan no registrasi. Label pada produk farmasi mempunyai peran yang amat penting terutama untuk kepentingan dan keselamatan konsumen sekaligus marketing tool. Salah satu aspek yang dinilai sebelum suatu obat diizinkan untuk boleh dipasarkan, adalah kelengkapan dan kebenaran informasi yang terdapat pada label obat (Sampurno, 2011).

Pernyataan "label berisi informasi obat yang jelas memastikan bahwa obat generik aman digunakan ketika sampai di tangan saya sebagai konsumen" berdasarkan rata-rata skor jawaban responden yaitu 3,31. Berdasarkan survei yang dilakukan, pada item pernyataan tersebut diketahui mayoritas yaitu 90 responden $(60,0 \%)$ menyatakan setuju.

Sejalan dengan hasil penelitian tersebut, item pernyataan terkait label obat yang lain yaitu pada pernyataan "saya percaya keamanan obat generik karena mencantumkan label yang lengkap (nama obat/zat aktif, tanggal kadaluarsa, indikasi, dosis/aturan pakai, nama \& alamat pabrik, no batch, dan no registrasi)", berdasarkan rata-rata skor jawaban responden yaitu 3,02. Berdasarkan survei yang dilakukan, pada item pernyataan tersebut juga diketahui mayoritas yaitu 110 responden $(73,3 \%)$ menyatakan setuju.

Sebagian besar responden yang menyatakan kesetujuan dengan 
Prosiding Seminar Nasional Kefarmasian, Hal: 25-39

Sabtu, 8 Oktober 2016, Hotel Aria Barito Banjarmasin

ISBN: 978-602-73121-1-1

tercantumnya label yang lengkap dan jelas dalam pemastian keamanan obat, secara tidak langsung menyiratkan bahwasanya konsumen memiliki minat yang baik dalam mendapatkan informasi obat dari label. Sementara itu, minoritas responden yang menyatakan ketidaksetujuannya dengan tercantumnya label yang lengkap dan jelas dalam pemastian keamanan obat secara tidak langsung menyiratkan kelompok pasien dengan minimnya minat konsumen dalam mendapatkan informasi obat dari label.

Minoritas responden ini menggambarkan kelompok pasien yang kecenderungannya memiliki trust yang tinggi dengan tenaga kesehatan baik itu dokter maupun apoteker. Setiap obat yang diberikan oleh tenaga kesehatan oleh pasien langsung dipercaya sebagai obat dengan kualitas yang baik dan pasien merasa cukup dengan penjelasan informasi singkat dari tenaga kesehatan. Pasien cenderung merasa kurang perlu untuk memeriksa label yang berisi informasi obat. Padahal label yang berisi informasi komprehensif mengenai informasi produk obat tersebut perlu diketahui oleh konsumen. Menurut Urbanus (2013), pasien pada kelompok minoritas ini menunjukkan minatnya untuk mendapatkan informasi obat dari label sebagai bentuk evaluasi keamanan obat cenderung hanya ketika mendapati efek samping saat mengonsumsi obat. Selain itu pada pasien dengan kondisi penyakit akut atau kronis, pasien yang merasa tidak mendapatkan pengobatan yang efektif, dan pasien yang pada saat yang bersamaan mengonsumsi beberapa obat sekaligus.

Sejalan dengan hal tersebut, laporan Syhakhang et al., (2004) menyatakan bahwasanya konsumen di beberapa negara berkembang memiliki trust terhadap dokter dan apoteker dalam penyedian obat yang berkualitas baik. Kecenderungan tersebut pada kelompok pasien ini juga karena mengingat sebagian besar responden menjadikan tenaga kesehatan baik itu dokter maupun apoteker sebagai sumber pengetahuan utama mengenai obat-obatan.

Trust yang tinggi terhadap dokter dan apoteker di satu sisi memang positif, tetapi seringkali dalam praktiknya tenaga kesehatan baik itu dokter maupun apoteker tidak punya cukup waktu untuk memberikan informasi mengenai obat yang akan digunakan oleh pasien yang bersangkutan. Oleh sebab itu minat konsumen dalam mendapatkan informasi obat dari label secara mandiri menjadi hal yang penting.

Minat konsumen dalam mendapatkan informasi obat dari label secara mandiri yang rendah tidak dapat 
Prosiding Seminar Nasional Kefarmasian, Hal: 25-39

Sabtu, 8 Oktober 2016, Hotel Aria Barito Banjarmasin

ISBN: 978-602-73121-1-1

sepenuhnya dipersalahkan kepada pasien semata, informasi obat yang terdapat di label seringkali dirasakan terlalu complicated bagi pasien awam sehingga pasien sangat malas untuk membacanya. Padahal label tersebut telah dipersiapkan secara serius oleh produsen yang bersangkutan dan dievaluasi secara cermat oleh Tim Evaluasi yang ada di Badan Regulatori Obat. Informasi yang ada dalam kemasan itu sebenarnya sangat bermanfaat bagi pasien (Sampurno, 2011).

Menurut laporan Institute of Medicine (IOM) Amerika Serikat tahun 2006 yang bertopik Preventing Medication Errors, disebutkan bahwa di Amerika Serikat setiap tahun terjadi lebih dari 1,5 juta kejadian efek samping obat lebih dari sepertiganya adalah pasien rawat jalan dengan nilai kerugian sekitar US\$ 1 milyar tiap tahunnya. Laporan tersebut menyatakan penyebab utamanya label obat yang menyebabkan terjadinya kesalahan medikasi (medication errors) dan Adverse Drug Event (ADEs) karena pasien tidak memahami dengan benar instruksi yang terdapat pada label obat. Oleh karena itu kemampuan pasien untuk mengerti dan paham terhadap instruksi yang terdapat pada label adalah sangat kritikal. Disamping adanya fakta bahwa informasi yang ada pada label kurang dipahami oleh pasien, sebagaimana diungkapkan sebelumnya para dokter dan apoteker di Amerika Serikat tidak punya cukup waktu untuk memberikan konseling mengenai obat yang akan digunakan oleh pasien yang bersangkutan (Sampurno, 2011).

Berbagai temuan di Amerika Serikat yang dilaporkan antara lain menyatakan kurangnya standar dan regulasi terkait labelling obat merupakan akar penyebab misunderstanding dan medication error. Dibutuhkan praktik evidence-based yang seharusnya berperan sebagai guide konten dan format labelling. Petunjuk penggunaan obat pada label sangat penting untuk pasien dan seharusnya ringkas serta jelas. Bahasa yang digunakan harus distandarisasi untuk meningkatkan pemahaman pasien guna pengobatan yang efektif dan aman. Labelling obat seharusnya dipandang sebagai bagian sistem yang terintegrasi dari informasi pasien (Sampurno, 2011). Menurut Engel et al. (1995) harapan yang diciptakan oleh label cukup kuat untuk mengubah persepsi konsumen atas produk.

Item pernyataan dengan skor terendah pada dimensi safety ditunjukkan item terkait efek samping obat. Menurut definisi WHO, efek samping obat merupakan segala sesuatu khasiat yang tidak diinginkan untuk tujuan terapi yang dimaksudkan pada dosis yang dianjurkan. Obat yang ideal bekerja secara selektif 
Prosiding Seminar Nasional Kefarmasian, Hal: 25-39

Sabtu, 8 Oktober 2016, Hotel Aria Barito Banjarmasin

ISBN: 978-602-73121-1-1

artinya hanya berkhasiat terhadap keluhan atau gangguan tertentu tanpa aktivitas lain.

Semakin selektif suatu obat terhadap target aksi tertentu, semakin kecil efek sampingnya dengan demikian semakin aman obat tersebut (Tjay dan Rahardja, 2002).

Pernyataan "dibandingkan dengan obat branded, obat generik memiliki efek samping yang lebih banyak", berdasarkan rata-rata skor jawaban responden yaitu 2,80. Berdasarkan survei yang dilakukan, pada item pernyataan tersebut diketahui meski mayoritas responden menyatakan setuju tetapi persentasenya hanya menunjukkan $\quad 70,7 \%$. Hal ini menggambarkan masih cukup banyaknya pasien yang meragukan keamanan obat generik ditinjau dari sisi efek samping obat.

Akan tetapi penilaian ini juga memungkinkan sebagai penilaian orang awam terhadap efek samping obat. Jika tidak ada keluhan-keluhan misalnya jantung berdebar-debar, mulut terasa kering, dan mual sebelum minum obat kemungkinan besar pasien memang mengalami efek samping obat. Akan tetapi pada dasarnya tidak mudah untuk membedakan apakah hal tersebut suatu efek samping atau gejala penyakit lain pasien, apalagi jika hal tersebut secara bersamaan. Hasil penelitian terkait hal yang sama oleh Al-Gedadi et al. (2008) menunjukkan persentase yang lebih tinggi, yaitu 127 responden $(31,2 \%)$ menyatakan bahwasanya obat generik lebih banyak efek samping dibandingkan dengan obat branded. Hasil penelitian oleh Mainar dan Arteida (2012) bahkan menunjukkan persentase yang lebih tinggi dibandingkan studi sebelumnya, yaitu 42,3\% responden menyatakan bahwasanya obat generik lebih banyak efek samping dibandingkan dengan obat branded.

\section{Persepsi Pasien Rawat Jalan di RS PKU Muhammadiyah Unit 1 Yogyakarta terhadap Kualitas Obat Generik Ditinjau dari Dimensi Efficacy}

Persepsi pasien rawat jalan di RS PKU Muhammadiyah unit 1 Yogyakarta terhadap kualitas obat generik ditinjau dari dimensi efficacy dapat dilihat tabel 3.

Dimensi efficacy berarti obat yang berkualitas harus dapat memberikan efek terapi yang diinginkan sesuai dengan indikasi yang telah ditentukan (Departemen Kesehatan RI, 1983). Efficacy merupakan respon maksimal yang dihasilkan suatu obat. Efficacy menurut konsumen didefinisikan sebagai potensi obat untuk menyembuhkan penyakit atau meredakan gejala penyakit (Syhakhang et al., 2004). 
Prosiding Seminar Nasional Kefarmasian, Hal: 25-39

Sabtu, 8 Oktober 2016, Hotel Aria Barito Banjarmasin

ISBN: 978-602-73121-1-1

Berdasarkan tabel 3, dapat diketahui bahwasanya rata-rata skor jawaban responden terkait dimensi efficacy adalah 2,75. Hal ini bermakna bahwasanya kualitas obat generik dari dimensi efficacy secara rata-rata dipersepsikan dengan baik oleh responden.

Tabel III. Distribusi Jawaban Responden tentang Persepsi Pasien Rawat Jalan di RS PKU Muhammadiyah Unit 1 Yogyakarta terhadap Kualitas Obat Generik Ditinjau dari Dimensi Efficacy

\begin{tabular}{|c|c|c|c|c|c|c|c|c|c|c|}
\hline \multirow[t]{2}{*}{ Pernyataan } & \multirow[t]{2}{*}{ Sub dimensi } & \multicolumn{2}{|c|}{ STS } & \multicolumn{2}{|c|}{ TS } & \multicolumn{2}{|c|}{$\mathbf{S}$} & \multicolumn{2}{|c|}{ SS } & \multirow[t]{2}{*}{ Rata-rata } \\
\hline & & $\mathbf{n}$ & $\%$ & $\mathbf{N}$ & $\%$ & $\mathbf{n}$ & $\%$ & $\mathbf{n}$ & $\%$ & \\
\hline $\begin{array}{l}\text { Dibandingkan dengan obat } \\
\text { branded, obat generik } \\
\text { bekerja kurang efektif }\end{array}$ & Kemanjuran & 14 & $9,3 \%$ & 122 & $81,3 \%$ & 14 & $9,3 \%$ & 0 & $0 \%$ & 3,00 \\
\hline $\begin{array}{l}\text { Obat generik merupakan } \\
\text { obat yang manjur dan ampuh } \\
\text { untuk mengobati gangguan } \\
\text { kesehatan yang saya alami }\end{array}$ & Kemanjuran & 8 & $5,3 \%$ & 30 & $20,0 \%$ & 101 & $67,3 \%$ & 11 & $7,3 \%$ & 2,77 \\
\hline $\begin{array}{l}\text { Dibandingkan dengan obat } \\
\text { branded, bagi saya obat } \\
\text { generik membutuhkan waktu } \\
\text { yang lebih lama untuk } \\
\text { memberikan efek yang saya } \\
\text { inginkan }\end{array}$ & Onset obat & 4 & $2,7 \%$ & 88 & $58,7 \%$ & 45 & $30,0 \%$ & 13 & $8,7 \%$ & 2,55 \\
\hline $\begin{array}{lrr}\text { Obat } & \text { generik } & \text { memberikan } \\
\text { hasil yang memuaskan } \\
\text { dalam } & \text { menyembuhkan } \\
\text { masalah } & \text { kesehatan yang saya } \\
\text { alami } & \end{array}$ & Kemanjuran & 8 & $5,3 \%$ & 38 & $25,3 \%$ & 100 & $66,7 \%$ & 4 & $2,7 \%$ & 2,67 \\
\hline Rata-rata Skor & & & & & & & & & & 2,75 \\
\hline
\end{tabular}

Keterangan:

STS: Sangat tidak setuju

TS : Tidak setuju

S : Setuju

SS : Sangat setuju

Seluruh rata-rata skor jawaban responden pada item-item pernyataan dimensi efficacy juga menunjukkan persepsi yang baik pasien terhadap kualitas obat generik. Hal ini secara umum bermakna pasien percaya dengan efficacy obat generik. Mayoritas responden yaitu 101 responden $(67,3 \%)$ menyatakan setuju bahwasanya obat generik merupakan obat yang manjur dan ampuh untuk mengobati gangguan kesehatan. Sejalan dengan hal tersebut, sebagian besar responden yaitu 100 responden $(66,7 \%)$ juga menyatakan bahwasanya obat generik memberikan hasil yang memuaskan dalam menyembuhkan masalah kesehatan yang dialami. Item pernyataan dengan skor tertinggi ditunjukkan pernyataan 
Prosiding Seminar Nasional Kefarmasian, Hal: 25-39

Sabtu, 8 Oktober 2016, Hotel Aria Barito Banjarmasin

ISBN: 978-602-73121-1-1

sama, mayoritas reponden yaitu $55 \%$ responden menyatakan bahwasnya obat generik sama efektifnya dengan obat branded. Demikian juga dengan hasil penelitian oleh Shrank et al. (2009) yang menunjukkan minoritas responden setuju bahwasanya obat branded lebih efektif dibandingkan dengan obat generik.

Onset merupakan kecepatan obat untuk mendapatkan efek terapi, waktu obat dikonsumsi sampai menimbulkan efek terapi. Item pernyataan dengan skor terendah ditunjukkan item terkait onset obat. Pernyataan "dibandingkan dengan obat branded, bagi saya obat generik membutuhkan waktu yang lebih lama untuk memberikan efek yang saya inginkan", berdasarkan rata-rata skor jawaban responden yaitu 2,55.

Berdasarkan survei yang dilakukan, pada item pernyataan tersebut diketahui mayoritas responden yaitu 88 responden $(58,7 \%)$ menyatakan tidak setuju. Terkait hal ini, hasil penelitian oleh Mainar dan Arteida (2012) menunjukkan 36,1\% pasien menyatakan setuju obat generik membutuhkan waktu yang sama dibandingkan obat branded untuk memberikan efek yang diinginkan.

Onset obat pada faktanya masih membutuhkan beragam parameter dan pengujian yang menjelaskan serta membuktikan hal tersebut. Onset obat generik dan obat branded generik kemungkinan sama dan kemungkinan juga berbeda. Hal ini tidak dapat terlepas dari beragam faktor yang mempengaruhinya salah satunya zat tambahan obat misalnya zat pengisi, pembawa, dan penghancur (IAI Bali, 2013).

\section{Persepsi Pasien Rawat Jalan di RS PKU Muhammadiyah Unit 1 Yogyakarta terhadap Kualitas Obat Generik Ditinjau dari Dimensi Acceptability}

Persepsi pasien rawat jalan di RS PKU Muhammadiyah unit 1 Yogyakarta terhadap kualitas obat generik ditinjau dari dimensi acceptability dapat dilihat pada tabel 4.

Dimensi acceptability berarti obat yang berkualitas harus dapat diterima oleh konsumen. Acceptability menyangkut bentuk sediaan obat, warna, rasa, dan kemasan yang menarik serta sesuai dengan keinginan konsumen sehingga dapat memberikan kepuasan kepada konsumen (costumer satisfaction) (Departemen Kesehatan RI, 1983) Acceptability menurut konsumen didefinisikan sebagai performansi obat untuk memenuhi keinginan konsumen. Acceptability merupakan tingkat kepuasan konsumen terhadap obat (Urbanus, 2013). Berdasarkan tabel IV, dapat diketahui 
Prosiding Seminar Nasional Kefarmasian, Hal: 25-39

Sabtu, 8 Oktober 2016, Hotel Aria Barito Banjarmasin

ISBN: 978-602-73121-1-1

bahwasanya rata-rata skor jawaban responden terkait dimensi acceptability adalah 2,73. Hal ini bermakna bahwasanya kualitas obat generik dari dimensi acceptability secara rata-rata dipersepsikan dengan baik oleh responden.

Tabel IV. Distribusi Jawaban Responden tentang Persepsi Pasien Rawat Jalan di RS PKU Muhammadiyah Unit 1 Yogyakarta terhadap Kualitas Obat Generik Ditinjau dari Dimensi Acceptability menunjukkan persepsi buruk terhadap kualitas obat generik, yaitu terkait tampilan obat.

Secara tradisional kemasan dimaknai untuk mewadahi dan melindungi produk (Sampurno, 2011). Pernyataan "obat generik memiliki kemasan yang meyakinkan bagi saya sebagai konsumen",

\begin{tabular}{|c|c|c|c|c|c|c|c|c|c|c|}
\hline \multirow[t]{2}{*}{ Pernyataan } & \multirow[t]{2}{*}{ Sub dimensi } & \multicolumn{2}{|c|}{ STS } & \multicolumn{2}{|c|}{ TS } & \multicolumn{2}{|c|}{$\mathbf{S}$} & \multicolumn{2}{|r|}{ SS } & \multirow[t]{2}{*}{ Rata-rata } \\
\hline & & $\mathbf{n}$ & $\%$ & $\mathbf{n}$ & $\%$ & $\mathbf{n}$ & $\%$ & $\mathbf{n}$ & $\%$ & \\
\hline $\begin{array}{l}\text { Obat generik memiliki warna } \\
\text { yang meyakinkan bagi saya } \\
\text { sebagai konsumen }\end{array}$ & Warna & 0 & $0 \%$ & 37 & $24,7 \%$ & 110 & $73,3 \%$ & 3 & $2,0 \%$ & 2,77 \\
\hline $\begin{array}{l}\text { Saya enggan menggunakan } \\
\text { obat generik karena rasanya } \\
\text { tidak enak }\end{array}$ & Rasa & 11 & $7,3 \%$ & 117 & $78,0 \%$ & 22 & $14,7 \%$ & 0 & $0 \%$ & 2,93 \\
\hline $\begin{array}{l}\text { Obat generik memiliki bentuk } \\
\text { yang meyakinkan bagi saya } \\
\text { sebagai konsumen }\end{array}$ & Bentuk & 0 & $0 \%$ & 17 & $11,3 \%$ & 131 & $87,3 \%$ & 2 & $1,3 \%$ & 2,90 \\
\hline $\begin{array}{l}\text { Obat generik } \text { memiliki } \\
\text { kemasan yang meyakinkan } \\
\text { bagi saya sebagai konsumen }\end{array}$ & Kemasan & 11 & $7,3 \%$ & 29 & $19,3 \%$ & 107 & $71,3 \%$ & 3 & $2,0 \%$ & 2,68 \\
\hline $\begin{array}{l}\text { Tampilan obat generik kurang } \\
\text { menarik bagi saya }\end{array}$ & Tampilan & 5 & $3,3 \%$ & 55 & $36,7 \%$ & 81 & $54,0 \%$ & 9 & $6,0 \%$ & 2,37 \\
\hline Rata-rata Skor & & & & & & & & & & 2,73 \\
\hline
\end{tabular}

Rata-rata skor jawaban responden pada item-item pernyataan dimensi acceptability menunjukkan persepsi yang baik pasien terhadap kualitas obat generik. Mayoritas responden yaitu $110(73,3 \%)$ dan 131 $(87,3 \%)$ berturut-turut menyatakan setuju bahwasanya obat generik memiliki warna dan bentuk yang meyakinkan bagi pasien sebagai konsumen. Sebagian besar responden yaitu $117(78,7 \%)$ menyatakan ketidakengganan menggunakan obat generik karena rasanya. Akan tetapi berbeda dengan dimensi kualitas obat lainnya, pada dimensi acceptability diketahui terdapat item pernyataan yang berdasarkan rata-rata skor jawaban responden yaitu 2,68. Berdasarkan survei yang dilakukan, pada item pernyataan tersebut diketahui mayoritas yaitu 107 responden $(71,3 \%)$ menyatakan setuju. Dapat dinyatakan fungsi kemasan yang secara tradisional dimaknai untuk mewadahi dan melindungi produk dengan demikian telah terpenuhi dengan baik menurut persepsi responden.

Akan tetapi, lebih dari sekedar fungsi kemasan yang secara tradisonal yang dimaknai untuk mewadahi dan melindungi produk; kemasan juga memiliki banyak fungsi untuk memberi nilai tambah bagi attractiveness produk 
Prosiding Seminar Nasional Kefarmasian, Hal: 25-39

Sabtu, 8 Oktober 2016, Hotel Aria Barito Banjarmasin

ISBN: 978-602-73121-1-1

dengan desain warna yang menarik serta deskripsi produk yang elegan sehingga mengundang orang untuk membeli dan menggunakannya (Sampurno, 2011). Menurut Hague dan Jackson (1993) produk yang kemasannya dirancang untuk memperbaiki produknya dan merangsang pelanggan sehingga menambah customer satisfaction. Jika kemasan membuat produk itu lebih menarik, kemasan itu memberinya nilai tambah. Menurut Peter dan Olson (2000) warna kemasan bahkan juga dianggap memiliki dampak yang penting terhadap afeksi, kognisi, dan perilaku konsumen. Dampak ini lebih dari sekedar menarik perhatian konsumen dengan cara menggunakan warna yang menarik perhatian.

Terkait dengan hal tersebut, pernyataan "tampilan obat generik kurang menarik bagi saya" berdasarkan rata-rata skor jawaban responden yaitu 2,37. Berdasarkan survei yang dilakukan, pada item pernyataan tersebut diketahui mayoritas responden yaitu $81 \quad(54,0 \%)$ menyatakan setuju. Obat branded generic tampilan kemasannya berwarna-warni dan menarik konsumen. Dibandingkan dengan obat branded generic, tampilan obat generik sangat sederhana. Obat generik dalam praktiknya seringkali diserahkan ke pasien tanpa kemasan. Konsumen bahkan kadang mendapatkan obat tanpa identitas nama obat sama sekali (Urbanus, 2013).

Terkait tampilan obat generik yang sangat sederhana ini, Direktur Jenderal Bina Kefarmasian dan Alat Kesehatan, Dra. Maura Linda Sitanggang, Apt., Ph.D menyatakan bahwasanya tampilan obat generik merupakan salah satu faktor penting yang menentukan keinginan pasien untuk memilihnya. Bentuk tampilan kemasan yang berupa botol-botol besar yang berisi obat dalam jumlah besar seharusnya sudah ditiadakan. Jika obat branded generic atau paten dikemas dalam bentuk strip, maka obat generik seharusnya juga demikian. Tampilan obat generik perlu dibuat lebih menarik, dengan demikian diharapkan citra obat generik akan menjadi lebih baik di masyarakat (Kartika, 2013).

Hasil studi terdahulu oleh Urbanus (2013) bahkan menyebutkan kemasan obat generik yang sangat sederhana menyebabkan konsumen meragukan safety dan efficacy obat. Akan tetapi, hal ini tidak tergambar dalam pelaksanaan penelitian ini. Meskipun berdasarkan survei yang dilakukan persepsi tentang tampilan dan kemasan (desain) obat generik termasuk kategori buruk responden tetap memiliki persepsi yang baik terhadap kualitas obat generik ditinjau dari dimensi safety dan 
Prosiding Seminar Nasional Kefarmasian, Hal: 25-39

Sabtu, 8 Oktober 2016, Hotel Aria Barito Banjarmasin

ISBN: 978-602-73121-1-1

efficacy obat. Kemasan obat generik sebagai indikator oleh pasien dalam melakukan penilaian kualitas obat generik juga sesuai dengan studi oleh Babar et al. (2010).

\section{KESIMPULAN}

Kesimpulan yang didapat berdasarkan penelitian yang dilakukan adalah persepsi pasien rawat jalan RS PKU Muhammadiyah Unit 1 Yogyakarta terhadap kualitas obat generik ditinjau dari dimensi safety, efficacy, dan acceptability secara umum baik.

\section{DAFTAR PUSTAKA}

Al-Gedadi, N.A., Hassali, M.A., dan Shafie, A.A., 2008. A pilot survey on perceptions and knowledge of generic medicines amongconsumers in Penang Malaysia. Pharmacy Practice, 6 (2): 93-97.

Anonim. 2012. Peraturan Menteri Kesehatan Republik Indonesia Nomor 40 Tahun 2012 Tentang Pedoman Pelaksanaan Jaminan Kesehatan Masyarakat. Kementerian Kesehatan Republik Indonesia, Jakarta

Babar, Z.U.D., Stewart, J., Reddy, S., Alzaher, W., Vareed, P., Yacoub, N., 2010. An Evaluation of Consumers' Knowledge, Perceptions, and Attitudes Regarding Generic Medicines in Auckland. Pharm World Sci, 32, 440-448.

Binfar Kementerian Kesehatan RI. 2014. Wawancara RCTI tentang Peredaran Obat Generik di Pasaran. http://www.binfar.org/wawancararcti-tentang-peredaran-obat-generik- di-pasaran/ Diakses tanggal 12 Agustus 2014

Departemen Kesehatan RI, 1983. Kebijakan Obat Nasional. Departemen Kesehatan Republik Indonesia, Jakarta.

Engel, J.F., Blackweel, R.D., dan Miniard, P.W., 1995. Perilaku Konsumen. Binarupa Aksara, Jakarta.

Excellus. 2007. Survey of Consumer AttitudesToward Generic Drugs. Excellus Blue Cross Blue Shield. 122.

Firth, J.D. 2001. Scientific Background of Medicine 2: Medical Masterclass. Royal college of physicians, London.

Hague, P. dan Jackson, P., 1993. Riset Pemasaran Dalam Praktik. Pustaka Binaman Pressindo, Jakarta.

IAI Bali. 2013. Salah Persepsi Obat Paten dan Obat Generik <http://www.ikatanapotekerindonesi abali.com/main/index.php/berita/beri ta-terbaru/86-salah-persepsi-obatpaten-dan-obat-generik//>. Diakses pada 23 Maret 2015

Igbinovia, M.E.. 2007. The Perceived Benefits of Generic Versus Branded Medicines. Tesis. Pretoria.

Jakarta Post. 2010. Distrust Keeps Generic Drug Use Low. Jakarta Post edisi 3 Agustus 2010.

Kartika, U., 2013. Cerdas Pilih Obat Generik Sukseskan JKN 2014, diakses pada 27Januari2015<http://health.kompas. com/read/2013/12/29/2046228/Cerd as.Pilih.Obat.Generik.Sukseskan.JK N.2014>.

Mainar, A.S. dan Arteida, N., 2012. Physicians' and Patients' Opinions on The Use of Generic Drugs. $J$ Pharmacol Pharmacother, 3 (3): 268-270.

Peter, J.P. dan Olson, J.C., 2000. Consumer Behavior Perilaku Konsumen Dan Strategi Pemasaran. Erlangga, Jakarta. 
Prosiding Seminar Nasional Kefarmasian, Hal: 25-39

Sabtu, 8 Oktober 2016, Hotel Aria Barito Banjarmasin

ISBN: 978-602-73121-1-1

Priyambodo, B. 2007. Manajemen Farmasi Industri. Global Pustaka Utama, Yogyakarta.

Sampurno, 2011. Manajemen Pemasaran Farmasi. Gadjah Mada University Press, Yogyakarta.

Shrank, W.H., Cox, E., Fischer, M.A., Mehta, J., dan Choudhry, N.K.. 2009. Patients' Perceptions Of Generic Medications. Health Aff (Millwood). Vol. 28 (2): 546-556.

Syhakhang, L., Freudenthal, S., Tomson, G., dan Wahlstrom, R., 2004. Knowledge and Perception of Drug Quality among Drugs Seller and Consumers in Lao PDR. Health Policy and Planning, 19 (6): 391401.

Syhakhang, L., Freudenthal, S., Tomson, G., dan Wahlstrom, R.. 2004. Knowledge and Perception of Drug Quality among Drugs Seller and Consumers in Lao PDR. Health Policy and Planning. Vol. 19 (6): 391-401.

Tjay, T. dan Rahardja, K., 2002. ObatObat Penting: Khasiat, Penggunaan, Dan Efek-Efek Sampingnya. Elex Media Komputindo, Jakarta.

Urbanus, C.B., 2013. 'Price and Brand Name as Indicators of Quality Dimensions for Generic Drugs', Tesis, MM, Universitas Gadjah Mada, Yogyakarta.

Waber, R.L., Shiv, B., dan Carmon, Z. 2008. Commercial features of placebo and therapeutic efficacy. JAMA, Vol. (9): 1016-1 